\title{
O PROCESSO DE APROPRIAÇÃO DA BIOEXPOSIÇÃO “A CÉLULA AO ALCANCE DA MÃO” EM UM CENTRO DE CIÊNCIAS: DESAFIOS DA MEDIAÇÃO
}

Fernanda Bassoli*

RESUMO: Os espaços não formais de ensino têm como principal função promover a divulgação científica e a popularização da ciência. A fim de proporcionar a inclusão social e a divulgação dos conhecimentos relativos ao corpo humano, foi desenvolvida pelo Museu de Ciências Morfológicas da UFMG a coleção de arte-educação "A célula ao alcance da mão". O presente trabalho tem como intuito relatar, efetuando um diálogo com o referencial teórico da área, o processo de apropriação dessa exposição pelo Centro de Ciências da UFJF, desde a etapa do planejamento à realização de pesquisas junto aos visitantes. Os dados obtidos reafirmam a importância de os espaços não formais investirem na formação de seus mediadores, como também de institucionalizar o registro de sua memória.

Palavras-chave: Centro de Ciências. Mediação. Bioexposição.

THE PROCESS OF APPROPRIATING BIOEXPOSITION “THE CELL AT HAND” IN A SCIENCE CENTER: CHALLENGES OF MEDIATION

ABSTRACT: The non-formal education spaces have as main function to promote scientific communication and popularization of science. In order to provide social inclusion and dissemination of knowledge on the human body it was developed by the Museum of Morphological Sciences of UFMG the collection of art education "The cell at hand." The present work aims to report, while having a dialogue with the theoretical references os the area, ABOUT the process of appropriation of this exhibition at Science Center (of UFJF), from planning the exhibition to surveying the visitors. The data reaffirm the importance of non-formal spaces investments in mediators training programs as well as in institutionalizing the record of their memory. Keywords: Science Center. Mediation. Bioexhibition.

\author{
*Graduada em ciências \\ biológicas pela ufJf e mestre em \\ ecologia pela ufrJ. professora \\ de ciências/biologia do colégio \\ de aplicação da universidade \\ federal de Juiz de fora (João \\ xxiii/ufJf). email: \\ fernanda.bassoli@ufjf.edu.br
}




\section{INTRODUÇÃO}

Os espaços de ensino não formal vêm ganhando destaque no Brasil desde a década de 1990 em função de seu importante papel de divulgação científica e popularização da ciência. Essas instituições têm consolidado a partir de então um compromisso institucional como serviço público, assumindo, de acordo com Marandino (2008), várias funções sociais: lugar de "coisas velhas", lugar de pesquisa científica, lugar de lazer, lugar de deleite, de educação e de diversão, sendo a perspectiva educativa alvo de maior interesse do público.

Esses espaços, ao assumirem o compromisso com a educação integral, buscam novas alternativas para melhorar o processo de comunicação com os seus visitantes no intuito de romper com modelos tradicionais de transmissão de conhecimento. Assim, segundo Gruzman e Siqueira (2007), a relação com o público tornou-se uma temática presente nos diferentes fóruns de discussão preocupados com o alcance, a abrangência e a qualidade de ações promovidas pelos espaços não formais.

Segundo Mora (2007), entre as últimas tendências nas visitas aos museus, especialmente aos de ciência, destaca-se uma abordagem cada vez mais próxima a um processo de questionamento, a fim de que o visitante - visto de forma individualizada consiga descobrir, analisar e interpretar o acervo ao seu passo e segundo suas necessidades e interesses. Entretanto, de acordo com essa autora, os museus e centros de ciência enfrentam um desafio comunicativo maior que os outros, pois ao construir suas exibições, em vez de exporem objetos já existentes, precisam assegurar que o que constroem e exibem irá estabelecer uma verdadeira comunicação com os seus visitantes.

Nesse contexto, os mediadores ganham grande destaque, uma vez que constituem um importante elo entre a instituição e o público. Segundo Marandino (2008), o mediador possui papel fundamental no controle da divulgação da informação pretendida, sendo considerado a "voz da instituição". Entretanto, são observadas, muitas vezes, proximidades e distâncias entre o discurso pretendido e o discurso real do museu.

Apesar da importância atribuída à mediação, o contexto em que ela ocorre ainda é pouco estudado, sendo tomado como cenário neutro na maioria das pesquisas (NASCIMENTO, 2008). Segundo Mora (2007), o máximo que se tem conseguido é um diálogo somente entre o especialista que comunica a ideia e um visitante razoavelmente versado nos temas abordados, restando ao espectador comum, no máximo, um pouco de diversão.

As explicações para isso residem no escasso trabalho multidisciplinar na criação de equipes de museu, conjugado ao fato de que são deixadas de lado as necessidades dos visitantes reais e potenciais; ao passo que a comunicação entre o objeto criado e o visitante é de fato observada quando realizada por meio de um mediador que conhece tanto as mensagens que o museu pretende quanto as necessidades particulares de cada visitante (MORA, 2007). Para tal, é necessário que essas instituições invistam fortemente na capacitação de seus mediadores.

Silva e Oliveira (2011), ao realizarem uma revisão de literatura sobre o papel dos mediadores, destacam uma série de funções atribuídas a eles: receber o público, auxiliar 
nos experimentos, dar informações e esclarecer dúvidas sobre as exposições, mediar processos de construção do conhecimento, concretizar a comunicação entre a instituição e o público, focalizar a atenção do visitante, provocar discussões, incitar a observação, orientar grupos, animar o ambiente, fazer a pergunta certa para aprofundar e enriquecer a experiência do visitante, dentre outras tantas; e concluem sobre sua formação:

[...] A competência profissional que cabe aos mediadores de centros e museus de Ciências é oriunda das próprias instituições, produto de suas tradições culturais e das pessoas que compõem esse contexto, legitimando os saberes que são necessários a um monitor em sua prática profissional, cabendo a esse ir apropriando-se dos elementos constituintes de sua prática profissional ao longo de sua formação (SILVA; OLIVEIRA, 2011, p. 55).

Além da mediação e comunicação, uma série de desafios se fazem presentes nesses espaços, especialmente a educação inclusiva, de modo que os programas de inclusão socioeducacional vêm ganhando, atualmente, visibilidade e apoio, tanto no Brasil como no exterior.

\section{“A CÉLULA AO ALCANCE DA MÃo"}

Embora as pessoas com deficiência tenham perante a lei todos os direitos do cidadão comum, os deficientes visuais ainda sofrem discriminação e contam, desde a educação básica, com poucos espaços de formação, o que representa dificuldade, atraso ou até mesmo obstáculo à sua qualificação profissional, à sua inserção no mercado de trabalho e ao desempenho de suas funções de cidadão (RIBEIRO, 2007). Nesse contexto, foi desenvolvida pelo Museu de Ciências Morfológicas da Universidade Federal de Minas Gerais (MCM) a coleção de arte-educação "A célula ao alcance da mão", que está sendo disponibilizada a diversas instituições a fim de possibilitar a divulgação de conhecimentos relativos ao corpo humano.

Inicialmente criada para atender as pessoas com deficiência visual, a exposição tem um caráter inclusivo e integrador por permitir a exploração das peças por vários órgãos dos sentidos - o que garante, também, um aspecto atraente, lúdico e interativo. A bioexposição é composta por 68 modelos biológicos, tridimensionais e em relevo, reproduzindo células, tecidos, órgãos, sistemas orgânicos, embriões e fetos humanos em diferentes estágios de desenvolvimento, apresentando diferentes texturas, relevos, cavidades e concavidades, que auxiliam no seu reconhecimento. Legendas em tipográfico e braile para cada peça da coleção facilitam a sua compreensão e possibilitam o trânsito relativamente independente do público-alvo, bem como o retorno às peças quantas vezes o visitante julgar necessário.

Também fazem parte da proposta metodológica o livro didático contendo informações teóricas essenciais à compreensão do conteúdo em estudo e a descrição detalhada de cada modelo da coleção, de modo a facilitar a sua utilização e contribuir para a independência do estudante/visitante - e o áudio livro - que possibilita a liberação de ambas as mãos para a exploração dos modelos enquanto se ouve as informações correspondentes, contribuindo para o processo de aprendizagem (RIBEIRO, 2007). 
A referida exposição foi doada ao Centro de Ciências da Universidade Federal de Juiz de Fora (UFJF) no fim de 2010, assim como tem sido disponibilizada a instituições de ensino formal e não formal, não só do Brasil como do exterior. Desse modo, a forma como essas instituições estão se apropriando da exposição nos fornece dados de grande relevância, não só em relação ao "feedback" que dão aos seus idealizadores, mas como instrumento de reflexão-ação para as pessoas que trabalham nela. Assim, são fornecidos subsídios para a utilização dessa exposição nos diferentes espaços educacionais e para novas pesquisas, a fim de que seu potencial inclusivo seja aproveitado ao máximo.

O presente trabalho tem como intuito promover a socialização dos conhecimentos produzidos durante todas as etapas que envolveram a organização da bioexposição - desde o planejamento das ações, a formação de recursos humanos, a execução das atividades/visitas, à realização de pesquisas junto aos visitantes do Centro de Ciências.

\section{METODOLOGIA DA INVESTIGAÇÃO}

Esta pesquisa foi desenvolvida segundo uma perspectiva qualitativa, a qual se preocupa com o "significado dos fenômenos e processos sociais" (PÁDUA, 2004, p. 36), reconhecendo a não neutralidade do pesquisador e valorizando o processo de coleta de dados, cuja análise se dá de forma interpretativa (BOGDAN; BIKLEN, 1994). Desse modo, descreveremos neste trabalho o processo de implementação da bioexposição "A célula ao alcance da mão" no Centro de Ciências da UFJF e os primeiros dados obtidos a partir das pesquisas realizadas com os visitantes, empreendendo um diálogo com o referencial teórico da área.

Durante o processo de implementação da bioexposição, entre setembro de 2010 e abril de 2011, foram realizadas reuniões semanais com os mediadores da área biológica, com duração de cerca de uma hora e meia, baseadas em uma perspectiva de reflexão sobre a prática (PIMENTA, 2008) e construção coletiva do conhecimento, privilegiando a troca de experiências e um diálogo horizontalizado entre todos os participantes.

As principais questões abordadas durante as reuniões foram registradas em um arquivo eletrônico. Foi criado também um caderno para registro das visitas à exposição e um formulário de avaliação (Anexo 1). Os professores que responderam aos questionários de avaliação foram identificados com números e os monitores citados foram identificados com letras.

\section{O CENTRO DE CIÊNCIAS}

Inaugurado no dia 26 de agosto de 2006, o Centro de Ciências da UFJF está localizado ao lado do Colégio de Aplicação João XXIII, em Juiz de Fora (MG). É um órgão de caráter multidisciplinar que desenvolve e apoia atividades relacionadas à educação científica em todos os níveis de ensino, contribui para a formação inicial de 
professores para a educação básica e investiga questões relacionadas à inovação dessa modalidade de ensino. O órgão desenvolve ainda atividades relacionadas à educação não formal e à divulgação das ciências e da cultura científica, a fim de despertar o interesse na população e nos estudantes. O espaço oferece atividades, cursos e programas de formação continuada para professores e realiza exposições de materiais pertencentes ao seu próprio acervo ou ao de outros centros de ciências (UFJF, 2011).

O Centro de Ciências possui um amplo salão que abriga exposições temporárias e experimentos interativos (Espaço Aprenda Brincando), predominando os relacionados à Física. Possui três laboratórios (Física, Química e Biologia), onde são realizadas atividades com os visitantes, sendo estes também disponibilizados aos professores de escolas desprovidas de laboratório; uma sala multimídia; secretaria; oficina; a Experimentoteca Pública (conjunto de "kits" experimentais de ciências que são disponibilizados às escolas); a Tabela Periódica Interativa (tabela periódica gigante com amostras e informações sobre os elementos químicos); o Jardim dos Sentidos, constituído de plantas que estimulam os órgãos sensoriais e a exposição permanente "A célula ao alcance da mão", dotada de uma sala própria.

Atualmente, o Centro de Ciências possui três roteiros de visitação, sendo responsável também pela direção do Museu Usina Marmelos Zero, a primeira usina hidrelétrica da América do Sul. O roteiro 1 envolve duas atividades nos laboratórios, uma sessão no Planetário e acompanhamento no salão de experimentos interativos. $\mathrm{O}$ roteiro 2 envolve a visitação à Tabela Periódica Interativa com atividades na sala de vídeo, sala de Informática e laboratório de Química. E o roteiro 3 (cujo desenvolvimento será descrito neste trabalho) envolve a visita à exposição "A célula ao alcance da mão".

A equipe do Centro de Ciências é formada por professores, pesquisadores, técnicos administrativos e estudantes da Universidade Federal de Juiz de Fora e do Centro de Ensino Superior de Juiz de Fora (CES/JF), com participação ativa do Colégio de Aplicação João XXIII (C.A. João XXIII) e do Instituto Federal de Educação Tecnológica (IFET/Juiz de Fora), pertencentes às áreas de Ciências Biológicas, Odontologia, Química, Engenharia Civil, Engenharia Elétrica, Ciência da Computação, Geografia, História, Turismo, Física, Matemática, Artes e Design, Comunicação Social; além de outras áreas que de alguma forma interagem com as atividades do Centro (UFJF, 2011).

O planejamento e a organização das atividades do Centro de Ciências são divididos por áreas: Astronomia, Biologia, Química e Física, sendo coordenadas por professores colaboradores da Universidade Federal de Juiz de Fora e do C.A. João XXIII, exceto a área de Química, que é coordenada pelo próprio diretor do Centro de Ciências da UFJF, atualmente lotado nessa mesma unidade. As atividades são executadas por alunos de graduação da UFJF e do CES/JF (no caso das Ciências Biológicas), bolsistas e voluntários, e também por funcionários técnico-administrativos da UFJF.

A seguir são apresentados os resultados e a discussão acerca do processo de implementação da bioexposição no Centro de Ciências. 


\section{DOS DESAFIOS AOS PRIMEIROS RESULTADOS}

A área biológica, até 2010, era a única área do Centro de Ciências desprovida de um professor orientador, apresentando grandes carências em termos de recursos humanos e de materiais didáticos. Coincidentemente, a chegada da exposição "A célula ao alcance da mão" ocorreu no mesmo período da contratação de uma professora de Biologia no C.A. João XXIII, que se dispôs a trabalhar também no Centro de Ciências.

Naquele momento, compunham a equipe: seis estudantes de Biologia da UFJF, a professora recém-chegada e uma bióloga com função administrativa no Centro de Ciências que havia sido monitora no período da graduação. Solucionado um problema, persistia outro, que era o reduzido número de mediadores naquela área.

A solução para esse impasse foi a realização de um convênio entre a UFJF e o CES/JF no início de 2011, a fim de possibilitar que os alunos do curso de licenciatura em Ciências Biológicas daquela instituição pudessem realizar os estágios supervisionados no Centro de Ciências.

Segundo Barzano (2008), a realização dos estágios supervisionados em espaços não formais é de grande importância para a formação dos futuros professores, uma vez que possibilita o contato dos licenciandos com outros modelos de instituições de ensino. Entretanto, de acordo com esse autor, a maioria das universidades brasileiras privilegia a escola como espaço para a realização do estágio supervisionado, havendo poucos estudos abordando a conexão entre espaço não formal e ensino de Biologia.

A exposição foi recebida em setembro de 2010. Uma equipe do Museu de Ciências Morfológicas da UFMG veio montá-la e realizou um curso de capacitação para a equipe do Centro de Ciências, baseado na abordagem dos conhecimentos de Biologia Celular, Histologia, Anatomia e Embriologia. O curso foi de grande valia, entretanto, após seu término, ficou o grande desafio para todos: Como seriam desenvolvidas as visitas à exposição?

Dois aspectos estavam claros naquele momento inicial: as visitas deveriam ser guiadas, tendo em vista os objetivos comunicacionais pretendidos, e a equipe precisaria se capacitar mais em termos de conhecimentos teóricos e metodológicos. Segundo a professora Maria das Graças Ribeiro, idealizadora da exposição, a presença constante de um mediador preparado é fundamental para o atendimento das diferentes demandas dos visitantes, uma vez que o estudo do corpo humano se apresenta difícil para a maioria do público (NASCIMENTO, 2008).

Então, para suprir essas carências, foram organizados encontros semanais com os membros da equipe da área biológica. No primeiro desses encontros, foi desenvolvida uma metodologia para a utilização da exposição, a qual foi testada em visitas experimentais. Nos demais encontros, discutiu-se a respeito das dificuldades, acertos e adequações necessárias, para só então inaugurar a nova exposição e abri-la para a visitação da comunidade. De acordo com Rodari e Merzagora (2007), são muito raros os casos em que os mediadores estão diretamente envolvidos nas primeiras etapas de planejamento da exposição, apesar de seu conhecimento sobre as necessidades do público. 
Segundo Marandino (2008), quando as equipes educativas dos museus desenvolvem ações para além das exposições, enfrentam o desafio de considerar as características referentes ao espaço, aos objetos, ao tempo e à linguagem, elementos os quais foram incorporados nas discussões semanais.

A metodologia inicialmente proposta foi pensada para atender a uma turma de 30 a 35 visitantes, uma vez que o público escolar é o mais frequente no Centro de Ciências. Em entrevista à diretora do MCM, realizada por Nascimento (2008, p. 18), também é relatada a prevalência do público escolar em sua instituição, perfazendo $82 \%$ dos visitantes que, segundo ela, buscam nesse espaço: "atualização de professores, melhoria do ensino de ciências, aulas práticas, motivação e até uma certa revitalização ou re-significação do ensino de ciências na prática escolar".

Para atender a esse público, seria necessária a divisão da turma em dois grupos, já que a sala da exposição não comportaria uma turma inteira de uma só vez. Uma atividade paralela deveria ser criada para que enquanto um grupo estivesse na sala da exposição, o outro estivesse em outra atividade. A equipe considerou que o ideal seria a conjugação da exposição com um vídeo que apresentasse uma perspectiva integradora dos níveis de organização dos seres vivos (das células ao organismo) e imagens o mais próximas possível do real. Isso permitiria aos visitantes contrastar os modelos vistos na exposição com a realidade, além de visualizar o funcionamento integrado das células, tecidos, órgãos e sistemas no organismo humano, os quais estão presentes na exposição de forma fragmentada.

A exposição do Centro de Ciências, por ser composta apenas por modelos de sistemas e órgãos do corpo humano em resina, não possibilita ao visitante o contato com peças reais, ao contrário do que acontece no MCM, que é dotado de um amplo acervo de peças anatômicas humanas conservadas, fotomicrografias de células e tecidos, embriões em diferentes estágios de desenvolvimento, técnicas de preparação de material para estudo em microscópios, além de esculturas em gesso e resina.

Desse modo, a importância do contato do público com o "real" foi um aspecto importante abordado pela equipe, tendo sido atestada pela professora Maria das Graças quando, em um dado momento, foi pesquisada junto aos visitantes a possibilidade de digitalização do acervo do museu: “[...] Nem pensar, responderam os visitantes entrevistados! Nada substitui o real. Aumentar os órgãos de tamanho, de cor (...) do jeito que se quer, já se pode fazer na internet. E nada substitui o real [...]" (NASCIMENTO, 2008, p. 19).

Após incansáveis buscas na internet e com professores que atuam na área, não foi conseguido o material com as características desejadas, de modo que a solução inicial foi realizar uma montagem com trechos de alguns vídeos obtidos na web, mesmo assim com qualidade aquém do esperado. Outra solução seria a utilização de um software na mesma perspectiva, mas que também permitisse a interatividade dos visitantes. Já havia um CD-ROM disponível no Centro de Ciências sobre citologia, voltado para o Ensino Fundamental, em que são explorados os componentes celulares e diferenças entre a célula animal e vegetal através de um jogo. Entretanto, essa mídia possui a limitação de 
apresentar imagens bem rudimentares e ser restrita à citologia. Mesmo com tais insuficiências, foi definido que ambos, o vídeo e o CD-ROM, seriam testados.

\section{AS PRIMEIRAS VISITAS: ERROS E ACERTOS}

Foram realizadas visitas experimentais com alunos do Ensino Fundamental e Médio do C.A. João XXIII e com adultos da Associação dos Cegos, ocorridas entre outubro e dezembro de 2010.

A primeira turma a visitar a bioexposição pertencia ao $8^{\circ}$ ano do Ensino Fundamental do C.A. João XXIII, vizinho ao Centro de Ciências, com visita programada para durar 40 minutos porque seria realizada durante a aula de Ciências.

A turma de 33 alunos foi dividida em dois grupos: um foi para a exposição com um monitor e a professora; e o outro, para a sala de informática. Na sala de informática assistiram a um vídeo de três minutos sobre células, tecidos e sistemas do corpo humano. Após o vídeo, puderam jogar dois jogos virtuais sobre células (CD-ROM).

Após a realização da primeira visita, a equipe se reuniu para a análise crítica sobre o que foi desenvolvido com os alunos. A exposição prendeu a atenção apenas de determinados alunos, um grande grupo ficou mais atraído pelos novos experimentos interativos do Espaço Aprenda Brincando e logo que terminaram de ver a exposição, dispersaram-se por ele. Dentre as peças da exposição, o feto foi o que mais atraiu o interesse dos alunos e muitos o quiseram pegar, de modo que o cordão umbilical foi quebrado na hora de colocá-lo de volta em seu lugar. A qualidade do vídeo realmente deveria ser melhorada, já os jogos atraíram bastante os alunos, embora eles tenham se preocupado mais em "fazer pontos" por tentativa e erro do que em entender o que estavam fazendo, indo na contramão da proposta do Centro de Ciências baseada na aprendizagem lúdica.

Outro aspecto interessante observado nessa primeira visita foi o retorno de um grupo de alunas ao Centro de Ciências para ver com mais calma a exposição e esclarecer dúvidas com os mediadores. Segundo a diretora do MCM, é comum os visitantes fazerem uma primeira visita de reconhecimento ao museu e depois voltarem a ele para estudarem melhor os sistemas e órgãos do corpo humano e suas respectivas funções e disfunções (NASCIMENTO, 2008). Esse fato atesta o interesse despertado pela exposição nessas alunas.

Com essas constatações, a demanda por um vídeo que fosse mais atrativo para os visitantes e de boa qualidade audiovisual permaneceu e o jogo virtual não atendeu às expectativas iniciais, uma vez que o seu potencial lúdico se sobrepôs ao aspecto educativo. Sobre esse aspecto, Marandino (2008) destaca que ao visitar o museu, o visitante busca o aprendizado, além de uma experiência prazerosa e divertida.

Assim, o grupo concluiu que a visita à exposição deveria ser mais bem coordenada, pois a exploração livre, ao menos pelo público escolar, gerou grande dispersão e danos às peças. Foi pensada, então, uma dinâmica para ser feita na sala de exposição a fim de envolver mais os visitantes com as peças. 
A dinâmica foi inspirada naquela realizada pelas professoras do MCM durante o curso de capacitação, em que a equipe foi dividida em grupos que receberam um envelope com perguntas relacionadas às peças cujas respostas deveriam ser indicadas colocando-se o cartão com a pergunta sobre a peça que correspondesse à resposta. Ao final, todas as perguntas foram conferidas com o envolvimento de todos.

Novas questões voltadas para visitantes do Ensino Fundamental e Médio foram então formuladas para a realização da dinâmica, a qual seria testada na semana seguinte com estudantes do Ensino Médio. Pela impossibilidade de se obter o vídeo desejado em tão pouco tempo, a visita seria conjugada com atividades no laboratório de Biologia, envolvendo a visualização de células e tecidos no microscópio óptico, suprimindo-se assim, o CD-ROM, com o jogo e o vídeo anteriormente mostrado.

\section{A INCLUSÃO SOCIAL NA EXPOSIÇÃO: UM OLHAR PARA A DEFICIÊNCIA VISUAL}

Em meio às discussões e realizações de visitas experimentais, o grupo ia ganhando confiança e experiência, ao passo que novas inquietações surgiam: "Como seria a visitação da exposição pelos deficientes visuais? Como deve ser a nossa mediação a fim de que melhor aproveitem a exposição? Qual a percepção deles sobre a exposição?”

Tendo em vista essas questões, o grupo realizou uma visita à Associação dos Cegos e foi recebido pela pedagoga responsável pelas atividades educacionais daquela instituição. Essa reunião foi de grande valia, pois várias dúvidas foram sanadas e o trabalho com deficientes visuais foi "desmistificado". Naquele mesmo dia, foi agendada uma visita experimental de um grupo de deficientes visuais à exposição.

A insegurança no atendimento às pessoas com deficiência é fruto da recente (embora tardia) implantação da educação especial-inclusiva e do consequente despreparo dos professores, quadro que se repete em todas as modalidades de ensino. Segundo Ribeiro (2007):

Com a mudança da legislação, determinando que as escolas acolham todos os estudantes, o sistema público de ensino, ainda que timidamente em decorrência da lentidão do próprio processo, vem implantando a educação especial-inclusiva. Para os professores, este ainda é um caminho novo: "sabemos que inclusão não se faz apenas com legislação, mas só conseguiremos avançar nesse processo com os deficientes dentro da escola, embora esta não seja, de início, uma situação agradável, nem para os deficientes nem para nós, ainda despreparados e sem recursos pedagógicos adequados" (idem, p. 5).

A visita do grupo da Associação dos Cegos foi de extrema relevância, uma vez que os visitantes não só apreciaram a exposição como também deram dicas importantes sobre sua organização e sobre a mediação que ajudariam não só os deficientes visuais, mas também os videntes, a melhor aproveitarem a exposição. 
Dentre essas dicas, ressaltaram a importância de se fornecer uma orientação espacial do local para que, possam transitar livremente por ele. Atentaram também sobre o tamanho das peças, uma vez que há peças em tamanho real e outras que são ampliadas, podendo gerar equívocos conceituais. Uma atividade sugerida pela pedagoga que os acompanhou foi a realização de uma dinâmica em que, por meio do tato, eles pudessem experimentar a consistência das estruturas do corpo humano por analogia, tocando materiais com consistências semelhantes. Outra questão levantada por ela foi a localização dos órgãos no corpo humano, noção que falta à exposição, o que pode ser sanado com a utilização de um torso humano desmontável e com a orientação de que eles tateiem o próprio corpo, a fim de perceberem a localização dos órgãos. Foi evidenciado, também, que os tipográficos em relevo, afixados à parede, não estavam acessíveis às mãos, uma vez que as bancadas com as peças se interpõem entre eles e o visitante - problema que persiste até hoje em função da falta de espaço para melhor colocá-los.

Para que todos pudessem participar da dinâmica das perguntas, estas foram transcritas em braile pelos próprios beneficiários da Associação dos Cegos.

\section{VISITA GUIADA: CRIANDO UM ROTEIRO}

Nas reuniões seguintes, foi definido que deveria ser criado um roteiro para uma visita específica à bioexposição, assim como já era feito com a Tabela Periódica Interativa, a fim de que o potencial educativo da exposição pudesse ser melhor explorado, tendo em vista que na visitação geral ao Centro de Ciências (Roteiro 1), que dura em média duas horas e meia, os visitantes passam por várias atividades envolvendo o planetário, os laboratórios de Física, Química ou Biologia e o Espaço Aprenda Brincando, sendo dedicados cerca de 20 a 30 minutos para cada atividade e mais um tempo para o lanche. Nessa perspectiva, se inserida a visitação à exposição, esta seria rápida e superficial, ao passo que poderia ser convidativa para uma próxima visita, exclusiva à exposição, conforme aconteceu na primeira visita experimental.

Assim, ao término de 2010 o grupo tinha a demanda de criar um roteiro específico para a visita à exposição, tendo como ponto de partida os erros e acertos das visitas experimentais anteriores. $O$ ano de 2011 começou, então, cheio de novas perspectivas para a equipe das Ciências Biológicas do Centro de Ciências, que ganhou mais sete mediadores em decorrência do convênio firmado com o CES.

Assim, a equipe dobrou de tamanho e a necessidade de formação tornou-se ainda mais evidente. Em função disso, logo em fevereiro foi organizada uma visita ao Museu de Ciências Morfológicas da UFMG com o intuito de motivar e contribuir para a capacitação da equipe que poria em prática o novo roteiro de visitação do Centro de Ciências.

A estada na UFMG durante dois dias cumpriu o seu papel motivador, formador e ainda contribuiu para promover uma maior integração entre os membros do grupo. No entanto, gerou nos estudantes uma ansiedade e insegurança mediante tantos 
conhecimentos que ainda deveriam ser consolidados, tendo em vista que a maioria deles ainda estava nos primeiros períodos da graduação.

Retornando a Juiz de Fora, as reuniões semanais foram retomadas e centradas na realização de seminários em que os membros da equipe foram divididos em subgrupos que realizaram apresentações sobre os conteúdos biológicos presentes na exposição, dando destaque à mediação com visitantes pertencentes a várias faixas etárias. Segundo Mora (2007), a discutir o papel dos mediadores e suas necessidades formativas:

O mediador deve, então, ter clareza dos objetivos de cada equipe e adequar seu discurso para as distintas idades, conhecimentos e interesses de um público muito variado e demandante. Por vezes, para envolver os visitantes na temática concreta das exposições, o mediador requer lançar mão da experimentação com novas formas de aproximação, de maneira que consiga familiarizálos com novas formas de leitura dos equipamentos exibidos e, por extensão, da própria instituição (MORA, 2007, p. 22).

Essa etapa de formação durou cerca de seis semanas, e nesse ínterim foi desenvolvido o roteiro para a visitação à exposição. Ao fim de março de 2011 a exposição foi oficialmente inaugurada e aberta ao público.

O novo roteiro envolve a visitação à exposição, atividades no laboratório de Biologia e uma oficina de modelagem de estruturas do corpo humano com massinha. As atividades no laboratório mostraram-se de grande importância por possibilitarem o contato dos visitantes com microscópios, acompanhado de explicações sobre seu funcionamento e sobre técnicas histológicas, que, ao ensejarem uma comparação entre modelo e realidade, ao mesmo tempo possibilitam a compreensão sobre a importância dos modelos para a ciência.

Segundo relatado por Nascimento (2008), a visita ao MCM é dividida em duas partes: primeiro os alunos assistem a uma palestra, com apresentação de filme/slides, que introduz o tema, e depois eles ficam livres para a visitação, estando os monitores à disposição para responder às dúvidas.

A instrumentalização da interatividade direta é realizada através de microscópios de luz e estereoscópicos, que permitem a visão micro e mesoscópica de células e outras estruturas. Nesse momento, é feita uma apresentação dos procedimentos técnicos de manuseio dos equipamentos, de sua importância para a ciência e de técnicas de preparação do material para estudo e pesquisa (NASCIMENTO, 2008, p.18).

No decorrer de 2011, o Centro de Ciências recebeu cerca de 21 mil visitantes e a visitação à nova exposição aconteceu tanto no Roteiro 1, com duração de cerca de 20 minutos, como também no roteiro exclusivo (Roteiro 3), durando cerca de 2 horas. Ambas as modalidades de visitação estão sujeitas a agendamento, atendendo aos visitantes de segunda a sexta-feira, com horários especiais no turno da noite.

No primeiro semestre, três dos seis estudantes que compunham a equipe no ano anterior saíram; ao passo que, no segundo semestre, a equipe foi quase que totalmente renovada, restando apenas dois dos mediadores presentes no primeiro semestre. A grande rotatividade dos bolsistas e voluntários é um sério problema no 
Centro de Ciências, uma vez que quando o mediador sai, leva consigo todo o conhecimento que construiu durante sua passagem, e o novo mediador e a equipe precisam reiniciar o processo de formação, recomeçando do zero.

Vários fatores são responsáveis pela saída dos estudantes: a grade curricular do curso de Biologia, que vai tornando-se mais apertada, o envolvimento dos alunos com outros projetos de pesquisa no Instituto de Ciências Biológicas e a conclusão do curso com o rompimento do vínculo com a UFJF, gerando a impossibilidade de recebimento de bolsa. Apesar disso, alguns mediadores permanecem mesmo após a conclusão do curso, seja como voluntários (caso de um dos membros da equipe que permanece no Centro desde sua inauguração até o presente momento, em função de seu grande envolvimento e satisfação pessoal com o trabalho realizado), seja como profissionais contratados, o que aconteceu com a bióloga que hoje ocupa o cargo administrativo e que, infelizmente, constitui um caso único. Sobre esse aspecto Mora (2007), destaca:

Para levar adiante sua tarefa com sucesso, os mediadores devem ser formados pelo próprio museu, de maneira que se sintam parte dele e possam imprimir uma personalidade própria à sua função. Desafortunadamente, poucos museus contam com guias especializados e sua função é desempenhada, ocasionalmente, por outro tipo de profissionais na forma de colaborações voluntárias (MORA, 2007, p. 22).

Esse problema torna evidente a carência de funcionários contratados para atuarem exclusivamente no Centro de Ciências, participando do planejamento, mediação, formação e pesquisa, de modo que os graduandos componham apenas uma fração dessa equipe e não a sua maioria, possibilitando, inclusive, sua contratação após a conclusão do curso.

No MCM, a equipe é composta por seis professores universitários, sete técnicos e dezesseis monitores, e o processo de formação destes dura cerca de um semestre letivo, sendo dividido em duas etapas:

[...] Estudo teórico-prático do conteúdo morfológico e afim, com avaliação oral; estudo do público e preparação para recebê-lo, com observação prática de 15 dias; paralelamente ao atendimento ao público o monitor ingressa lentamente em toda a rotina de trabalho do museu, após seminários e leitura de textos sobre museologia, museografia, difusão científica e toda a história e dinâmica do museu (NASCIMENTO, 2008, p. 16).

Apesar de o Centro de Ciências estar distante da situação relatada acima em termos da formação dos seus recursos humanos, há expectativas de que a mudança física para dentro do campus da UFJF, assim como sua ampliação, cujas obras iniciaram-se neste ano (2013), atraia mais recursos e, principalmente, mais professores interessados na divulgação e popularização da ciência e dispostos a compor uma equipe multidisciplinar e a consolidar um grupo de estudos e pesquisas. Desse modo, a UFJF certamente poderá contribuir mais efetivamente não só para a formação dos seus mediadores, como também para a formação de professores e para a difusão da ciência. 


\section{AS PESQUISAS E NOVAS PERSPECTIVAS}

Os dados analisados a seguir foram obtidos por meio de formulários de avaliação da visita (Anexo 1) preenchidos pelos professores/coordenadores que levaram seus alunos à exposição "A célula ao alcance da mão" (Roteiro 3). De maio a dezembro de 2011 foram realizadas dezenove visitas, todas elas feitas por instituições educativas de Juiz de Fora e região (cidades de Santos Dumont, São João Nepomuceno, Matias Barbosa e Leopoldina), e destas, doze professores/coordenadores preencheram o formulário. Do total de visitas, quatorze foram realizadas por escolas públicas, três por escolas particulares e duas por uma instituição sem fins lucrativos que atende a pessoas com necessidades especiais, principalmente com Síndrome de Down (Gráfico 1).

\section{Gráfico 1: Origens dos visitantes da exposição "a célula ao alcance da mão"}

\section{Visitantes da Exposição "A Célula ao Alcande da Mão"}

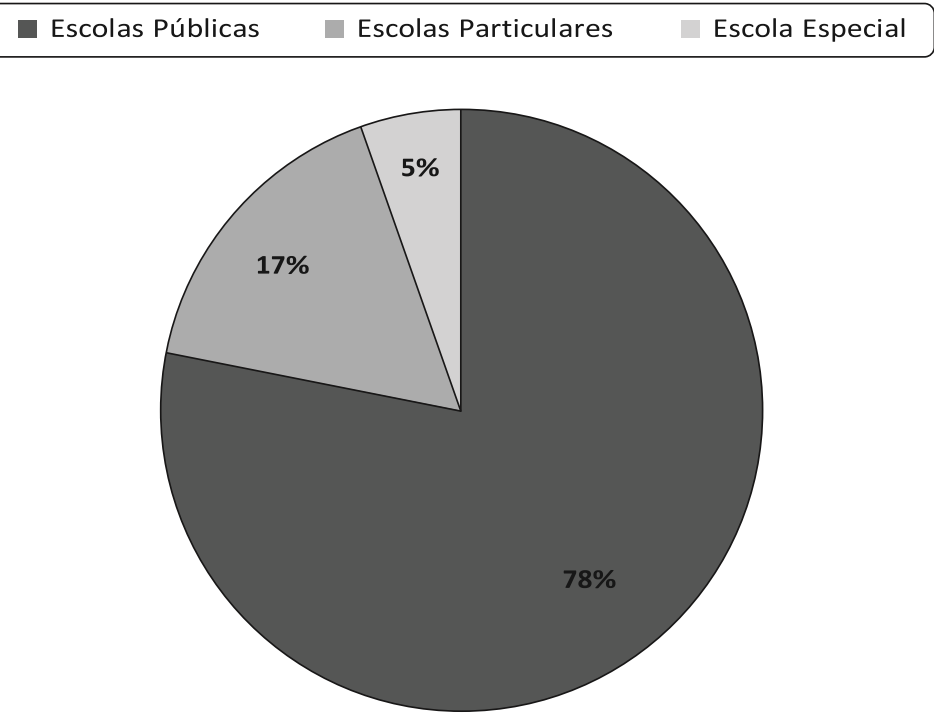

Em relação à escolaridade dos visitantes, uma visita foi realizada por estudantes da EJA (Educação de Jovens e Adultos), sete por estudantes do Ensino Médio e o restante por alunos do Ensino Fundamental, incluindo o primeiro segmento $\left(4^{\circ}\right.$ e $5^{\circ}$ ano), totalizando 552 alunos (Gráfico 2). 
Gráfico 2: nível e modalidade de ensino dos visitantes da exposição.

Modalidade/Nível de Ensino dos Visitantes

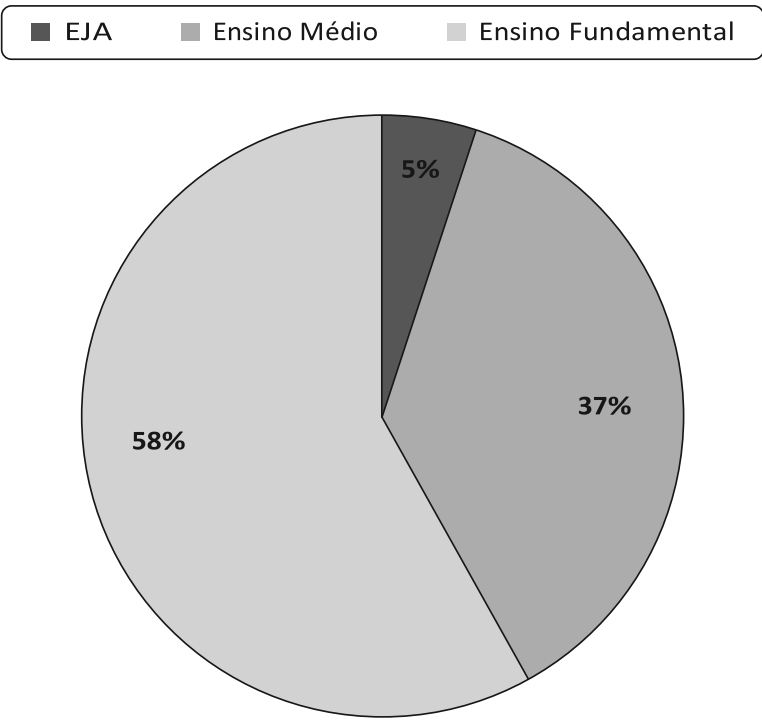

A avaliação do roteiro e da atuação dos mediadores (Gráfico 3) foi, em geral, muito positiva, uma vez que foram avaliadas com "ótimo” em onze dos doze formulários preenchidos, destacando-se os comentários:

O trabalho foi excelente, com a participação dos alunos, mediante planejamento das atividades realizado com eficácia dos profissionais do grupo(...) (Professora 1).

A visita foi de grande importância para o complemento da matéria dada em sala de aula (...) (Professora 2). 


\section{Gráfico 3: avaliação do roteiro da exposição e da atuação dos mediadores.}

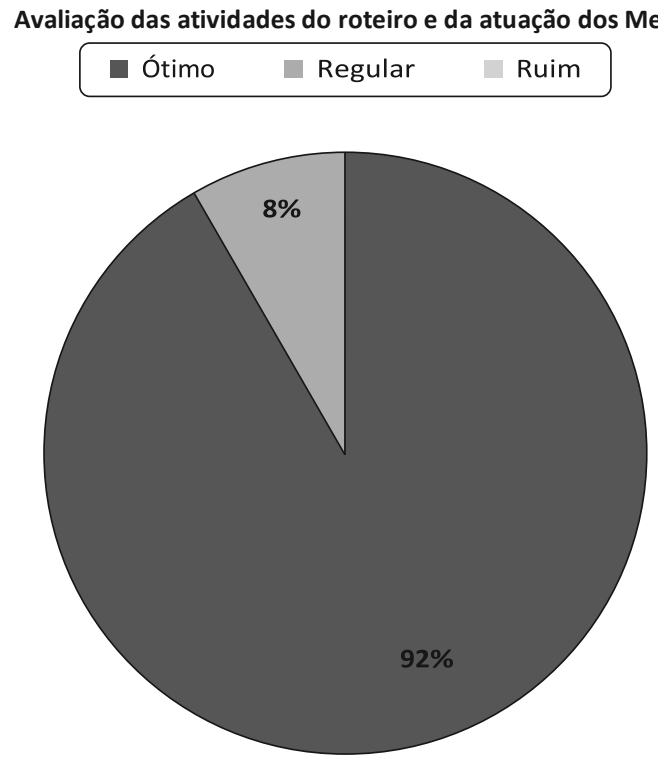

Em pesquisa junto aos visitantes, realizada por Leal e Gouvêa (2002) no Museu de Astronomia e Áreas Afins do Rio de Janeiro (MAST), das onze turmas que visitaram o museu durante o período investigado, dez foram de escolas particulares; o contrário do que aconteceu no Centro de Ciências, no período investigado, em que as escolas públicas tiveram presença mais marcante. Esse fato pode ser explicado pela maior carência de recursos didáticos e espaços apropriados para práticas nessas instituições, além da existência de convênios entre o Centro de Ciências e as redes públicas, o que vem atraindo professores para os cursos de formação continuada e faz com que eles tenham interesse de levar seus alunos para conhecerem esse espaço.

Outro aspecto importante é a maior flexibilidade curricular das instituições públicas em relação às particulares, em que o fator "tempo para se cumprir o programa" se faz mais efetivo (LEAL; GOUVÊA, 2002). As autoras destacaram, ainda, que a maioria dos professores, além de não pertencer à área de ciências, costuma levar seus alunos para fixar conteúdos que estão sendo trabalhados em sala de aula, o que é corroborado pelo comentário da Professora 2.

Apesar da prevalência das avaliações positivas supracitadas, em um dos formulários os itens "planejamento e organização das atividades realizadas no laboratório" e "atendimento ao grupo pelos monitores” receberam a avaliação "regular", o que foi justificado no item "sugestões" com o seguinte comentário:

Os monitores deveriam utilizar uma linguagem mais simples (de acordo com a série), pois utilizaram uma linguagem muito acadêmica (...). A monitora utilizou uma linguagem boa e um tom de voz bom" (Professora 3). 
Segundo Silva e Oliveira (2011), a linguagem utilizada pelos monitores está diretamente associada à compreensão da exposição, bem como a forma com que interagem com o público, o que requer um preparo e formação contínua desses profissionais:

\begin{abstract}
Adequar a linguagem visando à melhor comunicação e ao entendimento dos diferentes tipos de alunos, expressar-se de forma clara, simples, objetiva, divertida, correta e de acordo com a idade dos visitantes, foram atitudes que os monitores apontaram como essenciais na explicação dos conceitos científicos para os visitantes. Também destacaram que a explicação deve ser feita com dedicação, amor e felicidade, para auxiliar os visitantes no entendimento dos conceitos, além de ser cauteloso na escolha dos materiais a serem apresentados (SILVA; OLIVEIRA, 2011, p. 58.)
\end{abstract}

A última frase da professora destaca, também, a importância do tom de voz na atividade comunicativa. Em outro formulário, embora a Professora 4 tenha preenchido todos os itens com a avaliação "excelente", ela colocou no campo destinado a comentários no item 2.2:

Insegurança por parte do bolsista. Diç̧ão com dificuldade de interpretação. (Professora 4)

Segundo Rodari e Merzagora (2007), os mediadores são o único "artifício museológico" realmente bidirecional e interativo. Entretanto, para que essa interação se estabeleça com eficácia, o pressuposto básico é a linguagem, tanto em sua forma (tom de voz, boa dicção) quanto em conteúdo (correção conceitual e adequação aos vários públicos e faixas etárias). Mas, uma boa comunicação vai, ainda, além desses pressupostos, conforme afirmam esses autores:

De fato, nenhuma exposição interativa ou ferramenta multimídia pode realmente ouvir os visitantes e responder às suas reações. Tais reações podem variar entre perguntas estritamente informativas, do tipo "como isso funciona?", a comentários emocionais, como "isso me preocupa”. Mediadores podem adaptar suas apresentações e seus tipos de respostas não apenas a parâmetros gerais, como grupos de idade, mas também a aspectos mais sutis, o que caracteriza o desenvolvimento de uma boa conversa. Isso pode ser extremante recompensador, mas também é uma tarefa muito difícil (RODARI; MERZAGORA, 2007, p. 10)

Gomes da Costa (2007) reitera o aspecto já abordado neste artigo sobre a necessidade de uma sólida formação científica e tecnológica por parte dos mediadores, além dos aspectos comunicativos supracitados:

$\mathrm{Na}$ verdade, é muito mais fácil fazer um discurso que tenha sido anteriormente preparado que improvisar, no local, respostas às perguntas dos visitantes, a concepções errôneas ou dúvidas. Isso requer conhecimento científico profundo e confiança para desafiar o visitante a expor suas idéias para, então, construir a partir delas; requer uma familiaridade suficiente com a ciência e tecnologia para ser capaz de 'esquecer' as equações e as formulações padronizadas e conversar sobre ciência com o visitante - em vez de tentar ensinar ciência. Isso demanda uma boa formação científica e tecnológica, embora na maioria das vezes isso não seja suficiente: são essenciais prática 
e capacitação específicas para desenvolver a improvisação científica com precisão e as habilidades para dialogar sobre ciência (GOMES DA COSTA, 2007, p. 31).

Essas avaliações refletiram o esforço realizado para um atendimento de qualidade ao público, entretanto, o maior desafio enfrentado pela equipe do Centro de Ciências, que é a formação dos mediadores, persiste, evidenciando a necessidade de ações contínuas de formação, além de registros da memória do lugar (como está sendo feito neste artigo, por exemplo), para que todo o conhecimento produzido não se perca no tempo e no espaço, estando acessível aos novos membros da equipe.

As dificuldades enfrentadas durante o processo de apropriação da exposição, assim como as alternativas encontradas, descritas acima, foram sistematizadas no quadro abaixo (Quadro 1).

Quadro 1: sistematização das dificuldades e soluções encontradas durante o processo de apropriação da exposição "a célula ao alcance da mão"

\begin{tabular}{|c|c|}
\hline Dificuldades & Soluções \\
\hline Reduzindo número de mediadores. & $\begin{array}{l}\text { Realização de convênio com instituição particular } \\
\text { de ensino superior. }\end{array}$ \\
\hline Definição do tipo de visitação à exposição. & $\begin{array}{l}\text { Visita guiada. Elaboração de um roteiro de } \\
\text { visitação. }\end{array}$ \\
\hline Necessidade de capacitação da equipe. & $\begin{array}{l}\text { Realização de reuniões semanais. Visita e } \\
\text { capacitação no MCM }\end{array}$ \\
\hline Grande número de visitantes por vez. & $\begin{array}{l}\text { Divisão do grupo com realização de atividades } \\
\text { simultâneas. }\end{array}$ \\
\hline $\begin{array}{l}\text { Recursos didáticos para complementar a } \\
\text { exposição. }\end{array}$ & $\begin{array}{l}\text { Realização de visitas piloto com testagem de } \\
\text { vários recursos. }\end{array}$ \\
\hline $\begin{array}{l}\text { Despertar a atenção do público escolar para a } \\
\text { exposição. }\end{array}$ & $\begin{array}{l}\text { Criação de jogos e dinâmicas para a exploração } \\
\text { da exposição. }\end{array}$ \\
\hline $\begin{array}{l}\text { Atuação dos mediadores junto aos deficientes } \\
\text { visuais. }\end{array}$ & $\begin{array}{l}\text { Realização de visitas piloto com deficientes } \\
\text { visuais, ouvindo suas opiniões sobre a exposição } \\
\text { e metodologia utilizada. }\end{array}$ \\
\hline $\begin{array}{l}\text { Alta rotatividade dos mediadores, renovação } \\
\text { constante da equipe. }\end{array}$ & $\begin{array}{l}\text { Registro da memória do Centro de Ciências. } \\
\text { Registro das reuniões e redação de artigos. }\end{array}$ \\
\hline $\begin{array}{l}\text { "Feedback" dos visitantes em relação às } \\
\text { atividades realizadas e atuação dos } \\
\text { mediadores. }\end{array}$ & $\begin{array}{l}\text { Realização de pesquisas de público. } \\
\text { Questionários preenchidos por professores. }\end{array}$ \\
\hline
\end{tabular}




\section{CONSIDERAÇÕES FINAIS}

O processo de apropriação da exposição “A célula ao alcance da mão" não foi fácil nem simples. Enfrentamos dificuldades na aquisição de recursos materiais, na composição de uma equipe de mediadores e, principalmente, na formação dos mediadores para atuarem na exposição, tornando evidente o papel dos espaços não formais na consolidação tanto dos saberes sobre ciência e tecnologia, quanto dos saberes comunicacionais - os saberes da mediação - a fim de garantir ao público visitante um atendimento de qualidade. Entretanto, os frutos gerados pela exposição, expressos pela satisfação de seus visitantes e avaliação dos professores, fizeram valer a pena todos os esforços.

Os novos desafios envolvem a consolidação de uma equipe multidisciplinar, empenhada em investir na sua formação e em levar adiante novas pesquisas, como também em contribuir para o registro da "memória" da instituição de forma a superar o obstáculo da grande rotatividade dos mediadores com a consequente evasão dos saberes por eles construídos.

Desse modo, acreditamos que somente por meio do investimento na mediação humana é que novos conhecimentos poderão ser produzidos e difundidos à sociedade, de modo que a ciência esteja realmente ao alcance de todos.

\section{Agradecimentos}

Agradecemos a todos os monitores e estagiários do curso de Ciências Biológicas da UFJF e $\mathrm{CES} / \mathrm{JF}$ que atuam ou atuaram no Centro de Ciências. Agradecemos também à professora Maria das Graças Ribeiro, do Museu de Ciências Morfológicas da UFMG e sua equipe, pela receptividade, disponibilidade e atenção que tiveram conosco durante a implementação da exposição no Centro de Ciências, e aproveitamos para parabenizá-los pelo importante trabalho realizado em prol da inclusão social e popularização da Ciência.

\section{REFERÊNCIAS BIBLIOGRÁFICAS}

BARZANO, M. A. L. Educação não-formal: Apontamentos ao Ensino de Biologia. Ciência em Tela, vol.1, n. 1, 1-5, 2008. Disponível em: < http://www.cienciaemtela.nutes.ufrj.br/artigos/ Barzano_2008_1.pdf>. Acesso em: 09 jan. 2012.

BOGDAN R. C. E BIKLEN S. K. Investigação Qualitativa em Educação. Porto: Porto Editora, 1994.

CENTRO DE CIÊNCIAS DA UNIVERSIDADE FEDERAL DE JUIZ DE FORA UFJF, MG.

Disponível em: < http://www.ufff.br/centrodeciencias/home/centro-de-ciencias/>. Acesso em 20/12/11.

COSTA, A. G. Os "explicadores” devem explicar? In: MASSARANI, Luisa; MERZAGORA, Matteo; RODARI, Paola (orgs.). Diálogos \& ciência: mediação em museus e centros de Ciência. Rio de Janeiro: Museu da Vida/Casa de Oswaldo Cruz/Fiocruz, 2007, p. 27-30. Disponível em: $<$ http://www.museudavida.fiocruz.br/media/Mediacao_final.pdf>. Acesso em: 09 jan. 2012.

GRUZMAN, C.; SIQUEIRA, V. H. F. O papel educacional do Museu de Ciências: desafios e transformações conceituais. Revista Electrónica de Enseñanz̧a de las Ciencias, Vigo, ES, vol. 6, n 2, 402-423, 2007. Disponível em: < http:// reec.uvigo.es/volumenes/volumen6/ART10_Vol6_ N2.pdf>. Acesso em: 09 jan. 2012. 
0 processo de apropriação da bioexposição “A célula ao alcance da mão" em um Centro de Ciências: desafios da mediação

LEAL, M. C.; GOUVÊA, G. Narrativa, mito, ciência e tecnologia: O ensino de ciências na escola e no museu. Revista Ensaio Pesquisa em Educação em Ciências, Belo Horizonte, vol. 2, no. 1, p. 1-29, 2002. Disponível em: http://www.portal.fae.ufmg.br/seer/index.php/ensaio/article/viewFile/18/49. Acesso em: 09 jan. 2012.

MARANDINO, M. Ação educativa, aprendizagem e mediação nas visitas aos museus de ciências. In: MASSARANI, L. (Ed.). Workshop Sul-Americano \& Escola de Mediação em Museus e Centros de Ciência. Rio de Janeiro, Museu da Vida/Casa de Oswaldo Cruz/Fiocruz, 2008, p. 21-28. Disponível em: < http://www.museudavida.fiocruz.br/media/Mediador2008.pdf>. Acesso em: 09 jan. 2012.

MORA, M. C. S. Diversos enfoques sobre as visitas guiadas nos museus de ciência. In: MASSARANI, Luisa; MERZAGORA, Matteo; RODARI, Paola (orgs.). Diálogos \& ciência: mediação em museus e centros de Ciência. Rio de Janeiro: Museu da Vida/Casa de Oswaldo Cruz/Fiocruz, 2007, p. 2126. Disponível em: <http://www.museudavida.fiocruz.br/media/Mediacao_final.pdf>. Acesso em: 09 jan. 2012.

NASCIMENTO, S. S. O corpo humano em exposição: promover mediações sócio-culturais em um museu de ciências. In: MASSARANI, L. (Ed.). Workshop Sul-Americano \& Escola de Mediação em Museus e Centros de Ciência. Rio de Janeiro, Museu da Vida/Casa de Oswaldo Cruz/Fiocruz, 2008, p. 11-20. Disponível em: < http://www.museudavida.fiocruz.br/media/Mediador2008.pdf>. Acesso em: 09 jan. 2012.

PÁDUA, E. M. M. de. Metodologia: Abordagem teórico-prática. 10 ed. Campinas: Papirus, 2004.

PIMENTA, S. G. Professor reflexivo: construindo uma crítica. In: PIMENTA, Selma Garrido; GHEDIN, Evandro (Orgs.). Professor Reflexivo no Brasil: Gênese e Crítica de um Conceito. $5^{a}$ ed. São Paulo: Cortez, 2008. p. 17-52.

RIBEIRO, M. G. Inclusão Social em Museus. In: REUNIÓN DE L A RED DE POPULARIZACIÓN DE LA CIENCLA Y LA TECNOLOGIA EM AMERICA LATINA Y EL CARIBE RED POP UNESCO) Y TALLER “CIÊNCLA, COMUNICACIÓN Y SOCIEDAD”, 10, 4., 2007,

San José, Costa Rica. Anais... San José, Costa Rica: CIENTEC, 2007. Disponível em: <http:// www.cientec.or.cr/pop/2007/BR-MariaRibeiro.pdf>. Acesso em: 09 jan. 2012.

RODARI, P.; MERZAGORA, M. Mediadores em museus e centros de ciência: Status, papéis e treinamento. Uma visão geral européia. In: MASSARANI, Luisa; MERZAGORA, Matteo; RODARI, Paola (Orgs.). Diálogos \& ciência: mediação em museus e centros de Ciência. Rio de Janeiro: Museu da Vida/Casa de Oswaldo Cruz/Fiocruz, 2007, p. 07-20. Disponível em: <http:// www.museudavida.fiocruz.br/media/Mediacao_final.pdf>. Acesso em: 09 jan. 2012.

SILVA, C. S.; OLIVEIRA, L. A. A. Mediadores de Centros de Ciências e os seus papéis durante as visitas escolares. Revista Ensaio Pesquisa em Educação em Ciências, Belo Horizonte: v.13, n.02 , p.47-64. 2011. Acesso em: 09 jan. 2012. Disponível em: <http://www.portal.fae.ufmg.br/seer/index.php/ ensaio/article/viewArticle/229>. 
Anexo 1: Formulário de avaliação da exposição pelo professor.

Exposição "A célula ao alcance da mão"

Formulário de avaliação pelo professor

1. Receptividade ao grupo pela equipe do Centro de Ciências
( ) Ótimo
( ) Regular
( ) Ruim

2. Planejamento e organização das atividades realizadas durante a realização da visita:

2.1) Atividades realizadas na sala de exposição
( ) Ótimo
( ) Regular
( ) Ruim

2.2) Atividades realizadas no laboratório (microscopia)
( ) Ótimo
( ) Regular
( ) Ruim

2.3) Oficina de modelagem em massinha
( ) Ótimo
( ) Regular
( ) Ruim

3. Atendimento ao grupo pelos monitores do Centro de Ciências
( ) Ótimo
( ) Regular
( ) Ruim

4. Sugestões: 